\title{
Experiments in bilingual higher education: \\ An examination of the origins of Afrikaans as a second medium at the Transvaal University College, 1908-1930
}

\author{
Bronwyn Louise Strydom*
}

\begin{abstract}
In a multilingual society with a complex history of identity politics, language medium in South African higher education is a topic that frequently recurs and remains emotionally charged. As single medium institutions dominated the higher education landscape in the previous century, the history of multilingual educational endeavours has been somewhat neglected. This article considers the way the roles of different languages were negotiated at the Transvaal University College, forerunner of the University of Pretoria. It will examine not only the official life of the institution, but consider the way languages were dealt with in the college's student life. Motivations behind the introduction of Afrikaans as a second medium of instruction will also be considered. The way these events and circumstances related to notions of broad South Africanism, on the one hand, and growing Afrikaner nationalism on the other, will be highlighted. Some of the complexities which related to the bilingual policy of the college, as well as the defence of the policy by college authorities will be examined. In this way, the pitfalls and motivations behind the relatively short period of official bilingualism at the college will be investigated.
\end{abstract}

Keywords: Transvaal University College; University of Pretoria; higher education; language medium; bilingualism; broad South Africanism; Afrikaans.

\section{Opsomming}

In 'n veeltalige samelewing met 'n ingewikkelde geskiedenis van identiteitspolitiek, is die taalbeleid in Suid-Afrikaanse hoër onderwys 'n onderwerp wat gereeld verskyn en wat sterk emosies ontlok. Weens die feit dat in die hoër onderwys omgewing enkelmediuminrigtings dominant is, is die geskiedenis van veeltalige onderwyspogings ietwat versuim. Hierdie artikel beskou hoe die rolle van

* This article was written as part of a post-doctoral fellowship in the Department of History at the University of South Africa. Bronwyn Strydom now lectures in the Department of Humanities Education at the University of Pretoria. Her research interests include the history of universities and higher education in South Africa and related questions of identity politics.

How to cite this article: B.L. Strydom, "Experiments in bilingual higher education: An examination of the origins of Afrikaans as a second medium at the Transvaal University College, 1908-1930", Historia, 63, 1, May 2018, pp 72-92.

http://dx.doi.org/10.17159/2309-8392/2018/v63n1a4

Copyright: ()The Author(s). Published under a Creative Commons Attribution Licence. 
verskillende tale by die Transvaalse Universiteitskollege, voorloper van die Universiteit van Pretoria, verhandel is. Dit sal nie net die amptelike lewe van die inrigting ondersoek nie, maar ook die manier waarop tale in die kollege se studentelewe gehanteer is. Die motiverings agter die invoer van Afrikaans as 'n tweede medium van onderrig sal ook beskou word. Hoe hierdie gebeurtenisse en omstandighede met ideës van breë Suid-Afrikanisme, aan die een kant, en 'n groeiende Afrikaner nasionalisme aan die ander kant, saamgehang het, sal beklemtoon word. Die kompleksiteite wat verband gehou het met die tweetalige beleid van die kollege, sowel as die verdediging van die beleid deur kollegeverteenwoordigers sal ook in aanmerking geneem word. Op hierdie manier sal die moeilikhede en motiverings agter die betreklike kort tydperk van amptelike tweetaligheid by die kollege ondersoek word.

Sleutelwoorde: Transvaal Universiteitskollege; Universiteit van Pretoria; hoër onderwys; taalmedium; tweetaligheid; breë Suid-Afrikanisme; Afrikaans.

\section{Introduction}

Much has been written about Afrikaans as a medium of instruction in South African higher education from a number of different angles. This state of affairs, and the fact that it is often an emotionally charged subject, makes one hesitant to revisit the story of Afrikaans and its development as a medium of instruction at the Transvaal University College (TUC) - forerunner of the University of Pretoria (UP). However, in light of the current discourse surrounding Africanisation and endeavours to promote multilingualism in South African higher education, it is useful to consider these earlier attempts to foster a bilingual educational environment. ${ }^{1}$

This article considers the introduction of another medium (Afrikaans) to an institution of higher education almost a hundred years ago. The question of language medium in higher education in South Africa is a source of much scholarly interest, discussion and debate. ${ }^{2}$ The critical relationship between language and identity in a country with a diverse linguistic and ethnic population, makes language practice a matter which encompasses more than practical pedagogical considerations. While much attention has been focused on the place of languages in higher education in a multilingual society, less attention has been paid to the historical development of

1. Although this is not the main focus of this article, it is possible to trace many similarities in the discourse on Africanisation and the introduction of Afrikaans into the classroom, administration and student life of the Transvaal University College was not merely a matter of language but one of culture and aspirations to make higher education more locally relevant and accessible.

2. B. Brand, "Imagining a Multilingual Academy: Rethinking Language in Higher Education", South African Journal of Higher Education, 17, 3 (2003), pp 26-35; A. Foley, "Language Policy for Higher Education in South Africa: Implications and Complications", South African Journal of Higher Education, 18, 1 (2004), pp 57-71; L. Hibbert and C. van der Walt, Multilingual Universities in South Africa. Reflecting Society in Higher Education (Multilingual Matters, Bristol, Buffalo and Toronto, 2014). 
language mediums in South Africa in the tertiary education environment. The exception has mainly been the attention given to the development of Afrikaans as a medium of instruction at certain South African universities. ${ }^{3}$ These histories, however, have mainly been written from the triumphalist Afrikaner nationalist perspective which in many cases glosses over the more complex development of language medium policies and practices. In these histories, the transition to a policy of instruction exclusively in Afrikaans at certain educational institutions is presented as an inevitable development and there is a failure to consider the more complex motives and reasons behind the introduction of a different medium. This is particularly true of the account in UP's official history, Ad Destinatum. ${ }^{4}$

This article considers the narratives and reasoning with regard to the introduction of Afrikaans in the university lecture halls of the TUC. It will focus on the evidence about the initial introduction of Afrikaans into the social and official life of the institution. In this way, the discussion will focus on the motivations behind the introduction of a second medium at the college and on the decades of attempted bilingualism. ${ }^{5}$

In the period under discussion, from 1908 to 1932, white South African identity was in flux after the turmoil of the South African War and the change of the political dispensation. The blurring of definitions for white South Africans also included a somewhat fluid definition of language. By the beginning of the twentieth century, the Dutch language had developed into a local variation known as Afrikaans. Dutch, however, was used mainly as a written language and in formal settings, such as religious services, while Afrikaans was largely a spoken language. ${ }^{6}$ At this time Afrikaners sought to protect their language rights in the face of the British anglicising project, but which form of the language should be fought for was still a question of debate. Initially Dutch was favoured and as such it became an official language of the Union of South Africa in 1910.

The reality of the situation, however, was that many Afrikaners spoke Afrikaans and not Dutch. In these first few decades of the twentieth century, strengthened by the Second Language Movement, Afrikaans was gradually taking the place of Dutch until it replaced Dutch as the second official language in the country's

3. J.C. Steyn, “'n Rektor Skors sy Voorganger oor 'n Onstuimige Hoofstuk uit die Taalstryd aan die UKOVS", Joernaal ver Eietydse Geskiedenis, 20, 1 (June 1995), pp 87112; J.C. Steyn, "Die Taalstryd aan die Grey Universiteitskollege ten Tye van die Rektoraat van D.F. Malherbe", Acta Academica, 25, 4 (December 1993), pp 87-117; D.M. van der Merwe, "'Taal op Tuks': A Reappraisal of the Change in Language Policy at the University of Pretoria, 1932", Historia, 53, 2 (November 2008), pp 151-181.

4. C.H. Rautenbach et al (ed.), Ad Destinatum. Gedenkboek van die Universiteit van Pretoria (Voortrekkerpers, Johannesburg, 1960).

5. The focus of this article is not on UP's transition to a single medium policy in 1932.

6. H. Giliomee, The Afrikaners: Biography of a People (Tafelberg, Cape Town, 2009), pp 364-365 and 369. 
constitution alongside English. ${ }^{7}$ In the period while the Afrikaans language was being adapted to become not only a spoken language, but also a formal, written language which would take the place of Dutch, often the designations "Dutch" and "Afrikaans" were used interchangeably. This was certainly the case at the TUC where, for example, Afrikaans-speaking students were still referred to as Dutch, largely because their requests to have lectures presented in Dutch led, in reality, to lectures being given in Afrikaans. Likewise, in the college's student magazine, the contributions by Afrikaans-speaking students were selected by a Dutch editor while in fact the essays and poems were clearly not written in Dutch but in a language which more closely resembled modern Afrikaans.

The TUC began as an English medium institution in 1906 in Johannesburg. In 1908 the arts and science classes of the college were transferred to Pretoria. In 1910 the Pretoria and Johannesburg institutions separated officially, with the Pretoria college retaining its original name. Despite the fact that an examination of the first group of students and staff at the college showed outward signs of being a diverse white student body, the influence of the English language and culture was very marked in its early years. ${ }^{8}$ The English medium was in line with the plan devised by the high commissioner for South Africa and governor of the Transvaal, Lord Milner, to anglicise education. ${ }^{9}$ Books were only available in English and even college buildings were given English names. ${ }^{10}$ Furthermore, the influence of Britain on the entire South African university culture and system was also prevalent. In 1921, the TUC's first rector explained that "all parts of the Empire are looking to the Old Country as their spiritual home, the intellectual Mecca of our Commonwealth of Nations".11

The links to Britain at this time developed into a new kind of colonial nationalism which has been termed "broad South Africanism". According to this developing white identity, loyalty to the Empire was combined for English speakers with colonial nationalism. This movement to develop a new white identity in the

7. I. Hofmeyr, "Building a Nation from Words: Afrikaans Language, Literature and Ethnic Identity, 1902-1924", in S. Marks and S. Trapido (eds), The Politics of Race, Class and Nationalism in Twentieth-Century South Africa (Longman, New York, 1987), pp 103108; Giliomee, The Afrikaners, pp 364-369.

8. University of Pretoria Archives (hereafter UPA): D-1-2, TUC (Pretoria Branch) Register, 1908. Perusal of the names and backgrounds of students in the 1908 register shows there was an equal division between Afrikaans and English speakers and there is evidence of students with Jewish, German and French backgrounds.

9. Milner stated: "In the new Colonies the case will be easier to deal with, provided we make English the LANGUAGE OF ALL HIGHER EDUCATION". Cited (with capitalisation) in M.A. Basson,"Die Britse Invloed in die Transvaalse Onderwys, 18361907", Archives Yearbook for South African History,19, II (Government Printer, Pretoria, 1956), p 146. At the time, "higher education" referred to all teaching beyond primary school.

10. UPA: D-6-5-1-6-22, Tuks Alumni: "Herinneringe van Prof D.F. du Toit Malherbe".

11. "Universities of the Empire. The Pretoria Delegate: A Record of Impressions", Pretoria News, 6 September 1921. 
wake of the South African War, meant the laying aside of differences and embracing white South African diversity in an attempt to forge white unity. It is very similar to the policy of conciliation followed by the Het Volk Party under Louis Botha and Jan Smuts and their ideal of forging a unified white nation despite past differences. (Underlying this thought was the desire to unite in the face of a black majority.) Broad South Africanism embraced the notions of tolerance and understanding, with the thought that through mutual contact and respect, harmony would be established between the different sections of the white population. ${ }^{12}$ In the context of South African languages, broad South Africanism came to represent equal recognition for both white languages and even, in some settings, bilingualism. This unified nationality was, however, perceived as a threat by some Afrikaners who reacted by pursuing a more exclusive Afrikaner nationalism.

\section{Gestures at inclusivity}

Very early in the life of the Pretoria TUC, the desire to accommodate both white languages became evident. For example, one of the first matters brought up in a college council meeting of the newly independent Pretoria TUC in 1910,13 was a request to approach the council of the University of the Cape of Good Hope (UCGH) in order to acquire the right to use both official languages in its examinations. ${ }^{14}$ This request was only granted at a later date, but the fact that it was made as early as 1910, highlights the important role language rights were destined to play at the TUC. On the one hand this move emphasises the keen aspiration among some of the college authorities, even from these earliest years, to be more inclusive, while on the other hand it was an initial plea for Dutch (and later Afrikaans) to be given the same treatment as English. Broad South Africanist sentiment and its resultant endeavours to accommodate both languages is also quite evident in the way official college events were conducted in those formative years. In 1910, for example, when the cornerstone was laid of the Arts building in preparation for the move of the college to its own campus on the eastern side of Pretoria, speeches were delivered in both Dutch and English to a mixed crowd, representing the cream of white Pretoria society. ${ }^{15}$

12. S. Dubow, "Imagining the New South Africa in the Era of Reconstruction", in D. Omissi and A. Thompson (eds), The Impact of the South African War (Palgrave, New York, 2002), pp 76-95; A. Thompson, "The Languages of Loyalism in Southern Africa, c 1870-1939”, Oxford Historical Review, CVVIII, 477 (June 2003), pp 617-650; S. Dubow, "Colonial Nationalism, the Milner Kindergarten and the Rise of 'South Africanism', 1902-1910”, History Workshop, 43 (1997), pp 53-85.

13. In 1910 the Johannesburg and Pretoria branches of the TUC were split. The Johannesburg branch became known as the South African School for Mines and Technology; the Pretoria branch retained the name Transvaal University College.

14. UPA: B-4-1-2, Minutes of the Council: Minutes of the first meeting of the Council, 14 June 1910, p 6.

15. "The University Foundation Stone Laid by Lord Gladstone", Transvaal Leader, 4 August 1910. 
Despite these early symbolic signs of an inclusive stance on the part of college authorities, in practice the championing of equal language rights in these years was more evident among the student body. One of the initial indications of the broad South African ideal can be seen in the character of the first student society at the TUC, the Literary and Debating Society also known as the Letterkundige Debat-Vereniging which was established in 1908. The object of the society, embodied formally in its constitution was "the reading and criticism of essays, for debates, and ... the encouragement of literary composition in English, Dutch and Afrikaansch". ${ }^{16}$ It was divided into an English and a Dutch section with two respective chairpersons and furthermore the programme shows that debates and lectures were held alternately in each language. One of the first four professors, Prof D.F. du Toit Malherbe, used this society to point out that it was the students who were the first to distinguish between the languages. ${ }^{17}$ Later, when he reminisced over the formative years at the college he pointed out that "everything was English from A to Z except the students in their debating society". ${ }^{18}$ The first dramatic performance by students was presented in English and then in Dutch - a trend which was repeated in those early years. ${ }^{19}$

The proceedings of the Students Representative Council (SRC) also bear witness to a sensitivity among students on the use of both languages. An example is the matter of invitation cards for the first college dance which took place in 1909. The SRC minutes record that after some discussion, a decision was taken to print a number of the invitations in Dutch. Admittedly, this awareness seems to have been a little after-the-fact, because the printer had almost completed the English invitations and the print order was halted temporarily to have an additional number of Dutch cards made. ${ }^{20}$ These events bear witness to aspirations among the student body to be inclusive.

In November 1912, the students of the college published the first issue of The TUC Students' Magazine / Die Studenteblad van die TUK, which included student essays, poems and other literary contributions and offered interesting insights into students' perspectives. Even from the point of view of its layout, the magazine shows attempts to incorporate submissions written in English and/or Afrikaans and from both sections of the white population on equal terms. Furthermore, the English and Afrikaans version of the publication's name appears in equal dimensions on the cover. Each issue had a Dutch and an English editor and their separate editorials were printed in side-by-side columns in the opening pages of many of the early issues of the magazine, emphasising that no one language took preference over the other.

16. UPA: D-11-4-1, Transvaal University College Literary and Debating Society: Constitution.

17. Du Toit Malherbe said of the students: "Hulle is die eerste wat verskil gemaak het tussen die twee tale", see UPA, D-6-5-1-6-22, "Herinneringe van Prof D.F. du Toit Malherbe".

18. UPA: D-6-5-1-6-22, "Herinneringe van Prof DF du Toit Malherbe". My own translation.

19. Rautenbach (ed.), Ad Destinatum, p 391; UPA: D-11-3-1-2, Students' Representative Council Minutes, 1909-1914, 3 May 1910.

20. UPA: D-11-3-1-2, 3 September 1909. 
English and Dutch (or at this point a written language which more closely resembled Afrikaans) articles were roughly alternated and covered a wide variety of topics from more serious essays to comic sketches and poems. Thus, in a number of instances, the official student life of the TUC shows signs of attempts to foster a bilingual atmosphere and to place both white languages on an equal footing.

\section{Parallel demands for Afrikaans}

From the outset, however, narrower more exclusive interests in the place of Afrikaans ran parallel to broad South African sentiment. Both these currents are also evident in the first issue of the student magazine. ${ }^{21}$ What is striking, however, is the particular interest in the position of Afrikaans as a language in this first issue. It is also significant that students paid this kind of attention to the language in what was still a relatively early stage of the Second Afrikaans Language Movement. Another example of an endeavour to foster exclusive Afrikaans culture and language at the college was the establishment, in 1910, of the first discipline-related society, Loquela. This society's aims were to engage with both Dutch and Afrikaans literature and to speak both languages. Because Afrikaans was still in its infancy, most discussions were held in Dutch, giving students an opportunity to practise spoken Dutch. ${ }^{22}$

This interest in furthering the place of Afrikaans lined up with efforts nationally at this time to establish the language on equal terms with English in all spheres of life. ${ }^{23}$ In fact, the Afrikaans language grew impressively in the twentieth century to become the focus of Afrikaner culture and nationalism. After the South African War, the developing Afrikaans literature encouraged Afrikaners to stand against British influence and to introduce Afrikaans into education. Afrikaans writer, Eugene Marais, explained that Afrikaners had to recognise Afrikaans as their own language. If they did not, he warned that within a generation English would be the only language spoken by white people in South Africa. ${ }^{24}$ Under the surface, many English-speakers felt that in the end English would prevail as a natural matter of course. After Union, the South African Party government under Botha was inclined to let the issue of language take its course and allow for the "survival of the fittest". ${ }^{25}$ Furthermore, in line with their policy of conciliation towards English-speakers, Botha and Smuts were unwilling to insist on the matter of language. It was on this matter

21. H.H.B., "Die 'Praatkuns'”, The TUC Students' Magazine, 1, 1 (November 1912), pp 1113; NODROG, "Volksetymologie in die Afrikaans", The TUC Students' Magazine 1, 1 (November 1912), pp 25-26; R. Vale, "South African and the Africander", The TUC Students' Magazine, 1, 1 (November 1912), pp 14-15.

22. Rautenbach (ed.), Ad Destinatum, p 399.

23. The growth of Afrikaans has been investigated by a number of historians. See for example, Hofmeyr, "Building a Nation from Words", pp 95-123.

24. Basson, "Die Britse Invloed in die Transvaalse Onderwys", p 238.

25. Giliomee, The Afrikaners, p 362. 
that a growing Afrikaans intelligentsia took issue with the nationalism espoused by Botha, Smuts and Het Volk. ${ }^{26}$

Demands for the use of Afrikaans also became evident in the official student life of the college. In 1915, the SRC received a complaint from students about the exclusive use of English at general student meetings and in the reading of SRC minutes. A resolution was taken acknowledging that Dutch could be used at meetings and determining that in future the minutes would be read alternately in Dutch and English. The first recorded minute in Afrikaans followed this resolution and thereafter, the language generally alternated between Dutch and English. ${ }^{27}$

In the meantime, an increasing number of contributions in The TUC Students' Magazine demonstrated a concern for matters related to Afrikaner identity, particularly in the period following the outbreak of the First World War. ${ }^{28}$ These literary pieces were on the one hand a plea for Afrikaner rights, particularly related to language and an encouragement to remain true to Afrikaner heritage. On the other hand, a more extreme version was outright opposition to conciliation, white unification and broad South Africanism. It is significant that a good number of Afrikaans articles focused particularly on matters of higher education as they related to Afrikaners. These expressed the desire to transform the college into an Afrikaans institution and to take whatever steps necessary to realise this goal. ${ }^{29}$ The implication here was not merely the use of the Afrikaans language but also pointed to the penetration of a certain Afrikaans-oriented culture. This matched endeavours in popular Afrikaans magazines like Die Brandwag and Die Huisgenoot to repackage all aspects of life as being Afrikaans. ${ }^{30}$

\section{A second medium of instruction}

While on the student front the promotion of both official languages was more evident from an early date, it was almost a decade into the life of the institution that the

26. Giliomee, The Afrikaners, pp 358-359; M. Boucher, "The University of the Cape of Good Hope and the University of South Africa, 1873-1946: A Study in National and Imperial Perspective", Archives Yearbook for South African History, 35, I (Government Printer, Pretoria, 1974), pp 143-144; S. Marks and S. Trapido, "The Politics of Race, Class and Nationalism", in Marks and Trapido (eds), Politics of Race, Class, pp 11-12 and 17.

27. UPA: D-11-3-1-2, 17 April 1915 and 15 May 1915.

28. For example, Anon., "Gedagtes om die herkouw", TUC Students' Magazine, 1, 4 (November 1915), p 26; L.J. du P., "Ichabod”, TUC Students' Magazine, 2, 2 (November 1917), p 10; B. Strydom, "War, Education and Identity: Discord at the Transvaal University College (1914-1919)”, Historia, 59, 2 (November 2014), pp 194-209.

29. L.J. du P., "Ichabod", p 10; Van Rooy, "Editoriaal”, TUC Students' Magazine, 2, 3 (June 1918), pp 1-2; TIKKA, "Wat Ons als Afrikaners van die Hoofsetel van die Federal Universiteit van S.A. Kan en Moet Verwag", TUC Students' Magazine, 2,3 (June 1918), pp 15-16.

30. Hofmeyr, "Building a Nation from Words", p 111. 
college authorities first examined the language policy officially. In 1917 and 1918 the matter of the language medium was considered by the college's senate and council. Interestingly, the lengthy consideration was the result of action on the part of the students, highlighting the important role that students played in the language policy of the college. In April 1917, the senate received a request from students that lectures in Greek and History be given through the medium of Dutch. The senate's initial response was to note that although the majority of these classes would favour instruction in Dutch, there were students who did not understand Dutch. Senate requested that the TUC Council consider the matter. ${ }^{31}$ The chairperson of the council, Sir Johannes Wessels, wrote in a report on the matter that a single medium institution could offer a possible solution. This recommendation did not find favour in the council; it felt that the suggestion was neither "desirable or indeed practicable". ${ }^{32}$

In 1917, Prof D.F. du Toit Malherbe began to present lectures in Afrikaans to some of his senior students in Chemistry. According to Malherbe's own account, he extended these Afrikaans medium lectures to include those given to his first year classes the following year. ${ }^{33}$ However, a former student disagrees with this claim, explaining that a number of first year Chemistry students put together a memorandum in 1918 which was forwarded to the senate, accompanied by a petition signed by 77 students, requesting that the Chemistry lectures be given in Afrikaans. ${ }^{34}$ This student maintains that the request was refused but that this group of students was given permission to write the examinations in Afrikaans. He claims that Du Toit Malherbe then gave them a small brochure of chemical terms which he had translated into Afrikaans. Five students took the examinations in Afrikaans, after using Malherbe's brochure and a Dutch textbook which they had specially ordered from the Netherlands. ${ }^{35}$

The official UP historian, A.N. Pelzer credits Du Toit Malherbe's efforts with the awakening of national sentiment among Afrikaans-speaking students at the TUC. He states that as "if woken from a slumber, the generation of 1918 discovered itself and for the first time in the history of the T.U.C. showed signs of an enlivened national feeling". ${ }^{36}$ However, there are also claims that this awakening was already evident in 1917 as demonstrated by the students' request to the senate and was visible in the increased number of Afrikaans patriotic contributions in the student magazine.

31. UPA: B-5-1-1, Minutes of a regular meeting of Senate, 2 April 1917, p 212.

32. UPA: B-4-1-2, Minutes of meeting of the Council, 18 May 1917, p 202; Rautenbach (ed.), Ad Destinatum, $\mathrm{p} 48$.

33. UPA: D-6-5-1-6-22, "Herinneringe van Prof DF du Toit Malherbe".

34. This was more than a quarter of the student body of 325 students in 1918. UPA: A-1, Overview Histories, Studentegetalle (Student numbers)

35. UPA: D-6-5-1-6-22, Tuks Alumni Herinneringe, A-M, W.J. du P. Erlank - C.H. Celliers, 21 September 1974.

36. Rautenbach (ed.), Ad Destinatum, p 50. My own translation. UP's first official history, Ad Destinatum, was edited by then rector, Prof. C.H. Rautenbach, but it is widely accepted that much of the text was the work of A.N. Pelzer, a senior member of the UP Department of History. 
Certainly, the year 1918 saw an outpouring of interest and expression in matters relating to Afrikaans speakers and Afrikaner culture and heritage in the June edition of the magazine. ${ }^{37}$ By way of comparison, English language contributions remained apolitical, usually comprising humorous sketches or discipline related articles.

A former student at the college commented that 1918 was a very tense year at the TUC. The effects of the 1914 Rebellion and the First World War on South African society were reflected in the atmosphere at the college. ${ }^{38}$ These outside events had far reaching effects on the TUC and complicated endeavours to establish white unity. Furthermore, as one scholar has pointed out, in this climate, language was became increasingly "the key badge of identity". ${ }^{39}$ As such, it "posed a powerful, and in some ways unanswerable, challenge to proponents of a more inclusive colonial national (but ultimately Anglophone) construction of white nationhood". ${ }^{40}$ Certainly this "shift toward the reification of language as the primary signifier of identity, placed an inclusive, non-ethnic construction of national identity at a distinct disadvantage". ${ }^{41}$

The 1918 student petition to the senate concerning the language medium prompted college officials to consider the college's language policy in closer detail.42 The memorandum drawn up by the senate in response to the request illustrates the complexity of the issue and that there was no easy solution. The first conclusion the TUC senate reached was that the English-only policy was no longer workable. The senate did not, however, feel that it was wise to pursue a Dutch-only policy, reasoning that to do so would alienate Pretoria's English-speaking section. This policy might also mean that English-speaking students would prefer to enrol at the TUC's rival institution in Johannesburg. Then too, it was felt that duplication of courses was both impractical and undesirable. The senate also argued that any additional expenditure incurred because of the language medium issue should be covered by a special grant from the government. ${ }^{43}$ The solution reached was that each case should be considered on its merits "in a method of give and take ... relying on the good sense of the students and the public not to demand the impossible and unattainable". ${ }^{44}$ This

37. Van Rooy, "Editoriaal”, pp 1-2; TIKKA, "Wat ons Als Afrikaners van die Hoofsetel van die Federal Universiteit van S.A. Kan en Moet Verwag", pp 15-16; Anon., "Afrikaner, Wees Uself", TUC Students' Magazine, 2, 3 (June 1918), pp 30-31; M.K., "Alles Sal Regkom”, TUC Students' Magazine, 2, 3 (June 1918), pp 4-6; L.W.H., “Gedagte van 'n Afrikaner in 1918", TUC Students' Magazine, 2, 3 (June 1918), p 7; L.P., "Besware teen die Gees van Onse Eeuw", TUC Students' Magazine, 2, 3 (June 1918), pp 19-20.

38. UPA: D-6-5-1-6-22, W.J. du P. Erlank - C.H. Celliers, 21 September 1974; Strydom, "War, Education and Identity", pp 194-209.

39. J. Foster, Washed in Sun: Landscape and the Making of White South Africa (University of Pittsburgh Press, Pittsburgh, 2008), p 32.

40. Foster, Washed in Sun, p 32.

41. Foster, Washed in Sun, p 32.

42. UPA: B-5-1-1, Minutes of a regular meeting of Senate, 4 March 1918, p 247.

43. UPA: B-5-1-1, Re Medium Question at the Transvaal University College, 1 May 1918, $\mathrm{p}$ 253; Rautenbach (ed.), Ad Destinatum, p 51.

44. UPA: B-5-1-1, Re Medium Question at the Transvaal University College, $\mathrm{p} 253$. 
attitude, in essence, was in accordance with the idea of compromise and cooperation embodied in the broad South African ideal. The senate also opted for a vague solution - much like the ill-defined application of conciliation - and expressed the hope that when student numbers increased, there would be the means to appoint more staff and provide bilingual instruction. Furthermore, there was the belief that the gradual introduction of a dual medium policy in schools would eventually solve the medium question at the college. ${ }^{45}$

Thus, the underlying issue which lacked resolution in all aspects of the new Union of South African, including university affairs, was the matter of equality between the two white races. What this meant in effect and how it would be carried out in practical terms, was uncertain. It was entrenched in the language clause of the Union in 1910 and the quest for language rights became a topic of ongoing debate. ${ }^{46}$

The TUC then approached the minister of education about the matter and proposed that a solution lay in the complete duplication of all courses. The minister's response to an interview with the council and senate on the medium question was to send out a circular to all the country's universities and colleges in which he stated that the "bilingual student ... be regarded as the normal student". ${ }^{77}$ Because the expense of duplicating professors and lecturers was considered out of the question for the foreseeable future, the minister's suggestion was that instruction be divided into English and Dutch medium subjects, as circumstances demanded, at the discretion of the council.48 Thus, the college was left with the unsolved problem of how to deal with the language medium question, again highlighting the ambiguities and difficulties at the heart of broad South Africanism. As mentioned earlier, broad South Africanism in terms of language was equated with bilingualism, but at this point bilingualism, like broad South Africanism, was not well-established among white South Africans.

The TUC's reaction to the minister's circular was that the matter could only be resolved if English and Dutch were both made compulsory subjects for entrance to the country's universities. ${ }^{49}$ In June 1918 a joint meeting of the senate and council was held to consider the conundrum in light of the circular. ${ }^{50}$ After this meeting a response to the minister's circular was drawn up. The council felt that the minister

45. UPA: B-5-1-1, Re Medium Question at the Transvaal University College, $\mathrm{p} 253$.

46. Boucher, "University of Cape of Good Hope and University of South Africa", pp 147148.

47. UPA: B-5-1-1, Appendix: Copy of circular from Under Secretary for Education, 12 June 1918, p 261.

48. UPA: B-5-1-1, Appendix: Copy of circular from Under Secretary for Education, p 261; Rautenbach (ed.), Ad Destinatum, pp 51-52.

49. UPA: B-5-1-1, Minutes of a special meeting of Senate, 17 June 1918, p 264.

50. UPA: B-4-1-2, Minutes of special joint meeting of Council and Senate, 27 June 1918, $p$ 230. 
was premature in his view that the bilingual student should be considered the normal student. ${ }^{51}$

There were in essence three objections to the minister's proposal to divide courses between the two mediums. Firstly, the TUC's council felt that it was "a wellknown fact" that English students did not possess sufficient knowledge of the language to be able to follow lectures in Dutch. Thus, presenting certain subjects in English and others in Dutch would be a risky policy for the college. Secondly, this would "certainly cause English students to congregate in colleges where the medium is bound to be exclusively English". This would impact negatively on the TUC and due to the proximity of the English medium college in Johannesburg, the TUC would invariably become exclusively Dutch. This would give rise to a third problem, namely, the withdrawal of "the sympathy of English-speaking people of Pretoria" from the college which would have "a disastrous effect on the finances of the College". ${ }^{2}$ The TUC was thus caught in a difficult position: having opened the door to the Afrikaans medium with a view to accommodating Afrikaans-speaking students' interests, it now stood at risk of alienating English-speakers, thus highlighting the tenuous foundations of broad South Africanism and attempted bilingualism. The TUC felt that although it would be costly, the "ideal solution of the difficulty is a duplication of teaching staff" and once again urged the minister to consider the temporary measure of appointing extra professors. ${ }^{53}$

In September 1918 another ASB deputation to the senate requested that emphasis be laid on the appointment of bilingual professors in the newly established Faculty of Agriculture or that those appointed in posts in the faculty acquire an adequate command of the second language within two years. The senate appointed a sub-committee to consider a practical scheme for 1919 regarding the language medium throughout the TUC. ${ }^{54}$ Based on its findings, the senate replied to the ASB, making reference to the minster of education's earlier circular. A "transitional solution" was offered as eight academic departments were prepared to offer classes in either medium on a first year level the following year, depending on the wishes of the majority of students in those classes. ${ }^{55}$

Throughout the 1920s the TUC senate repeatedly received requests and petitions from students for the use of Dutch as a medium in specific courses. For example, in February 1920, 19 students out of a class of 27 in the subject Philosophy asked for lectures in Dutch. This request was declined, based on the "present

51. UPA: B-4-1-2, Minutes of special joint meeting of Council and Senate, 27 June 1918, p 231.

52. UPA: B-4-1-2, Minutes of special joint meeting of Council and Senate, 27 June 1918, $p$ 231.

53. UPA: B-4-1-2, Minutes of special joint meeting of Council and Senate, 27 June 1918, p 231.

54. UPA: B-5-1-1, Minutes of a regular meeting of Senate, 11 September 1918, p 278.

55. UPA: B-5-1-1, Secretary of the Senate - Secretary ASB, 26 September 1918, p 280. 
pressure of work in the Department" ${ }^{56}$ History lecturer, Leo Fouche raised a similar question regarding History lectures. ${ }^{57}$ The following month saw a petition from students studying Geology that lectures be given in Dutch, to which the registrar replied that the "medium question" was "at present under consideration". 58 This was indeed the case because a special commission had been set up to examine the college's policy on the language issue; it was to report back to the senate. The decision was made to divide the departments of the college into Dutch medium and English medium departments subject to the agreement of the heads of these departments. From 1921 there would be eight Dutch medium departments at the TUC, with the option for the possible duplication of classes in both mediums in the case of larger groups of students.

The TUC was making a valiant attempt to negotiate the vague and murky waters of a bilingual language policy and therefore expressed outrage in 1921 when the vice chancellor of the University of South Africa saw fit to predict that in the future, to cater for both languages, there would be an English-medium university in Johannesburg and a Dutch-medium university in Pretoria. Speaking at the university's graduation, Dr W.J. Viljoen foresaw a repetition in the Transvaal of the situation in the Cape Province where the universities of Stellenbosch and Cape Town presented lectures in Dutch and English respectively.

The senate and council of the TUC responded strongly, distancing the college from Viljoen's statement and emphasising "this College has always striven to do justice to both sections of students",59 and that it "deprecates the suggestion that this College will become a purely Dutch College". 60 Thus it can be seen that endeavours to further the cause of Dutch as the medium of tuition were not at this stage part of an overarching plan to transform the entire college into a purely Dutch-medium institution - in the early 1920s the TUC distanced itself strongly from the notion of a single medium. ${ }^{61}$

\section{"A hot-bed of nationalism"}

In September 1922 the TUC turned to the public press to refute a charge which had been made by a well-known Pretoria lawyer at a South African Party gathering that the college had become "a hot-bed of nationalism". ${ }^{2}$ On closer inspection, the charge

56. UPA: B-5-1-1, Minutes of Senate, 27 February 1920, p 263.

57. UPA: B-5-1-1, Minutes of Senate, 27 February 1920, p 263.

58. UPA: B-5-1-1, Minutes of Senate, 27 March 1920, p 301.

59. UPA: B-5-1-1, Minutes of Senate, 13 April 1921, p 352.

60. UPA: B-4-1-2, Minutes of Council, 17 June 1920, p 303.

61. The main comment in the Dutch press focused on the fact that Dr Viljoen had made his speech in English for a second successive year. Complaints appeared in De Volkstem and De Zuid Afrikaan. See De Volkstem, 12 April 1920; and De Zuid Afrikaan, 13 April 1920.

62. "Politics and the TUC: Dr Reinink's Letter, a Reply from Mr A. Davis.", Pretoria News, 5 September 1922. 
was made not because there were so-called nationalist professors or students who promoted Afrikaner nationalism. In this case the very fact that certain scientific subjects were taught through the medium of Afrikaans was seen by English-speakers as a form of aggressive nationalism. ${ }^{63}$ The accuser continues:

... the fact that these subjects are lectured in Afrikaans also means that Englishspeaking citizens will not send their sons to the T.U.C. any more than they would to Stellenbosch. No consideration is shown to the English-speaking student. Although efficiency and common-sense demand English as a medium in certain subjects, militant Nationalist Jingoism demands Afrikaans and gets its way, and the English-speaking student becomes an "outsider" where he should be at home. ${ }^{64}$

Another letter to the editor demonstrates similar arguments. The fact that certain science subjects were only available to students at the TUC through the medium of Afrikaans was considered unacceptable. The writer argues that "Practically all the Dutch in South Africa are bilingual, and wonderful bilingualists they are - good luck to them. But how many bilingualists are there amongst the English?"65 Significantly this writer highlights the assumption that the new South African white identity would be Anglophone.

It is noteworthy that the issue here relates to science subjects being taught through the medium of Afrikaans. It is also worth reflecting on the fact that the first subject given through the medium of Afrikaans at the TUC was Chemistry. It may perhaps have been expected that History or another humanities subject would be the first presented in Afrikaans. This would have lined up with idea of a heritage and identity being closely linked to the language and, as indicated earlier, the senate felt that these subjects would be naturally suited to the medium. The fact that Chemistry was first taught in Afrikaans (to be followed later by other science subjects) is what caused the strong public reaction. These subjects necessitated the development of a specific scholarly vocabulary in Afrikaans, an effort which was considered unjustifiable by those who voiced objections in the Pretoria press. ${ }^{66}$ It is also significant that the instruction of scientific subjects in the medium of Afrikaans raised the language to a scholarly and academic level and thus placed it more on par with English.

The TUC replied that in accommodating a second medium, it was giving due recognition to the other official language of the Union. The unwillingness of the college to pursue a unilingual policy was given as evidence of its alignment with

63. "Politics and the TUC: Charge Refuted", Pretoria News, 25 August 1922; "The TUC: A Question of Medium", Pretoria News, 2 September 1922; "Politics and the TUC: Dr Reinink's Letter", Pretoria News, 5 September 1922.

64. "Politics and the T.U.C: Dr Reinink's Letter", Pretoria News, 5 September 1922.

65. "The TUC: A Question of Medium", Pretoria News, 2 September 1922.

66. "The TUC: A Question of Medium", Pretoria News, 2 September 1922; "Politics and the TUC: Dr Reinink's Letter", Pretoria News, 5 September 1922. 
broad South African ideals. In addition, it was pointed out that at this stage $75 \%$ of students were Dutch speaking and needed to be accommodated. Thus, the college's language medium policy at this stage represented an attempt to be inclusive and foster diversity, as TUC's Prof Reinink explained:

It is all very well to say that the English-speaking section of the population of the Union has a legal right to education through its own language; if so, the Dutchspeaking section must be allowed exactly the same right. ... If anywhere, then certainly on the college benches - a spirit of understanding and appreciating one another's feelings and traditions can and must be developed. ${ }^{67}$

Professor Reinink also commented on the large amount of time which had been devoted to discussions on the language medium question in the senate. ${ }^{68}$ Following the debate in the press, students at the TUC made their own voice heard on the matter of language by holding a general meeting. In the crowded college hall, the meeting concluded "that bi-lingualism in the college is absolutely desirable". ${ }^{69} \mathrm{~A}$ report in the press describes the proceedings as follows:

The debate, though prolonged, was of a most amicable nature and both English and Dutch students testified to the complete harmony existing between the two sections of the College. Not a single voice was raised in defence of uni-lingualism. Every speaker professed himself imbued with the fact that bi-lingualism was the only way out of the difficulty and every speaker laid stress on the fact that all personal considerations should be subordinated to the greater ideal of a bilingual college as an example to South Africa, an institution worthy of the Administrative Capital of the Union, and a true embodiment of the principles of bi-lingualism and toleration. ${ }^{70}$

For others, however, the bilingual policy was too closely mixed up in political considerations to merit its serious pursuit at the college and had even caused the atmosphere at the TUC to become, in their opinion, "violently disturbed". ${ }^{71}$ Furthermore, the college found itself in a difficult place because the council was aware that a number of Afrikaans-speaking students were planning to go to Grey College in the Orange Free State in order to have certain classes in Afrikaans. ${ }^{72}$ In the meantime, the senate set itself the impossible task "to subordinate considerations of medium to the maintenance of the highest possible efficiency in the work of the College, but subject to this to do all it can to meet the legitimate claims of both

67. "Medium Question: Another Open Letter", Pretoria News, 12 September 1922.

68. "Medium Question: Another Open Letter", Pretoria News, 12 September 1922.

69. "Language and the TUC: Students' Scheme, Bilingualism the Ideal”, Pretoria News, 19 September 1922.

70. "Language and the TUC: Students' Scheme, Bilingualism the Ideal", Pretoria News, 19 September 1922.

71. "The TUC", The Pretoria News, 21 September 1922.

72. UPA: B-4-1-2, Minutes of Council meeting, 2 November 1922, p 438. 
sections of the population". ${ }^{73}$ The critical factor in furthering facilities for instruction in both English and Afrikaans remained the need for additional funding. ${ }^{74}$

\title{
The University of Pretoria
}

Despite the undercurrents which had surfaced in the 1920s, when the TUC received its university charter in 1930, becoming the University of Pretoria (UP), the chief function of the institution was still understood by some to be its unifying and nationalising role in line with broad South Africanism and that this be reflected in its bilingual medium. Speaking on this occasion, UP's first chancellor, Justice Tielman Roos, highlighted the necessity of "absolute language equality" at the university; these languages were the two pillars upon which the future of the country would be built. ${ }^{75}$ Roos reminded his audience that this was reminiscent of the dream of a national university, and ideal first pursued by educational administrators almost two decades earlier:

\begin{abstract}
We must not make this in the narrow sense of the word an African or an Afrikaans University; but, in the widest sense of the word a South African University. (Applause.) It will be for the first time in South African history; because I do not regard any university as a South African university unless both languages are known when the students leave it - it may be the most wonderful university in the world, but unless they know both languages it will not be a South African university. ... If it becomes a purely Afrikaans University it will be the graveyard of my hopes; if it becomes an English University it will the graveyard of my hopes; but if it becomes a South African University in the fullest sense of the word we may fear no graveyard of our hopes, but enjoy the realisation of our aspiration fully. ${ }^{76}$
\end{abstract}

Two years later, however, the council of the University of Pretoria decided that in terms of the language medium, the university would cater primarily for Afrikaans speakers. The decision to move away from the bilingual 50-50 policy was the final blow to broad South Africanist aspirations at the institution. ${ }^{77}$ To use the words of Tielman Roos, the decision became the "graveyard" of such hopes - the hopes of

73. UPA: B-5-1-1, Minutes of a regular meeting of the Senate, 20 June 1923, p 454.

74. UPA: B-5-1-1, Minutes of a regular meeting of the Senate, 20 June 1923, pp 454-455.

75. "To Unify South Africa is the Ideal of the University of Pretoria: Chancellor's Statement of Policy", Pretoria News, 13 October 1930.

76. "To unify South Africa is the Ideal of the University of Pretoria: Chancellor's Statement of Policy", Pretoria News, 13 October 1930.

77. Interestingly, even in this decision there is evidence that the ideal of broad South Africanism had not yet waned completely. The then rector (A.E. Du Toit) motivated the adoption of an Afrikaans-only medium policy to the UP council but Du Toit's tone is not as militantly Afrikaner nationalist as later Afrikaner nationalist writing portrayed him. Instead it appears he made numerous attempts over a long period to maintain and promote the bilingual 50-50 policy. See for example, UPA: D-6-5-1-6-22, Tuks Alumni Herinneringe: Ad Destinatum I, Briefwisseling met oudstudente en ander instansies: A.E. du Toit - Chairman of the Council, 17 August 1932. 
bilingualism and broad South Africanism were dashed. Indeed, shortly before the adoption of the single medium policy at UP, the director of education in the Transvaal, S.P.E. Boshoff was quoted in the Rand Daily Mail of 29 August 1932, as hinting that:

... virtually every educationalist will admit, that the whole structure of education in this province is being wrecked on bilingualism, on an ideal which, in very many cases, is utterly impracticable, at any rate so far as the schools are concerned. It is a political rather than an educational ideal. ${ }^{78}$

Boshoff touched here on the ideological significance of language in education as well as the practical difficulties of accommodating multiple language mediums. Both these matters are seen clearly in the writing of the students in The TUC Student Magazine and in the senate and council's lengthy considerations of how to implement a dual medium policy.

Giliomee has commented that the "language issue was the weak spot of the Het Volk leaders". ${ }^{79}$ They did not take a definite stance on the matter of language, hoping that the issue was resolve itself. ${ }^{80}$ The minister of education, F.S. Malan's response to the TUC demonstrates the weak response of government to this critical question. Furthermore, the attempts by the TUC council and senate to deal with the matter highlight the difficulties of applying broad South Africanism in practice. It has aptly been called a paradigm that was "engagingly idealistic and pragmatically vague". ${ }^{81}$ Opening the door to the Afrikaans medium in the name of conciliation raised questions of practice to which there were no simple answers and in the end undermined the very ideal of broad South Africanism which it was trying to promote. In a sense, the very pursuit of broad South Africanism was regarded as menacing by some Afrikaners, who reacted by defending and promoting a distinct cultural identity even more strenuously. Afrikaners' claims for language equality can therefore be interpreted as defensive action to preserve their distinct identity. Ironically, the terms of broad South Africanism, which envisaged a unified white identity, were employed to justify these claims.

However, it can be argued that broad South Africanism and the bilingual ideal endured for at least two decades at the TUC despite the simmering dissatisfaction on the language medium question. It was an ideal, embodied in what became known as the 50-50 policy, which the staff in particular, endeavoured to embrace. It was also a point of pride throughout the period of the college. For example, at the time of the passing of the University Act in 1916, the TUC was "proud of its claim to be the only college to foster a truly bilingual approach". ${ }^{2}$ Two dozen years later, a 1932

78. "Bilingualism Wrecking Education", Rand Daily Mail, 29 August 1932. Boshoff was referring mainly to primary and secondary education but the thought can also be applied to higher education.

79. Giliomee, The Afrikaners, $\mathrm{p} 271$.

80. Giliomee, The Afrikaners, $\mathrm{p} 362$.

81. Foster, Washed in Sun, p 30.

82. Boucher, "University of the Cape of Good Hope and University of South Africa”, p 174. 
advertisement in the Cape Times, prior to the change in policy, still announced proudly that UP was the "only FULLY BILINGUAL University Institution in South Africa". 83

The pessimist view of bilingual education is that it represents merely a period of transition in the path to the establishment of a dominant language. According to Laponce:

A bilingual school and university system generally has only the appearance of equality. Even when it is balanced at the level of courses it is in fact unbalances in favour of the dominant language, which dominates the environment outside the school. Bilingualism in education is thus generally a bilingualism of transition, which in the long run facilitates linguistic assimilation. ${ }^{84}$

While ultimately the institution did choose to follow a single medium policy after 1932, the preceding two decades represented a concerted endeavour to further a bilingual environment. Furthermore, the way the language medium policy was dealt with in the college's senate and council, and to an extent, the role the student voice played in the matter, indicate that the drive to establish the place of Afrikaans was more random and unpremeditated than one gathers from the account in the institution's official history.

This state of affairs is also evident in the later recounting of the circumstances of the burning of the British flag on the TUC campus in 1919. The student responsible for what later became known as "the flag incident", W.J. du P. Erlank, ${ }^{85}$ emphasises in his version of the incident that the sentiment of furthering Afrikaans interests at the TUC did not represent an organised movement. 86 This corroborates Van der Merwe's criticism of the account on the language issue that appears in Ad Destinatum, where it is described as a focused struggle to establish the place of Afrikaans. ${ }^{87}$

Thus, with regard to the official policy on the language medium, it is certainly not as simple a matter as Pelzer suggests in Ad Destinatum. He claims that the TUC

83. Cape Times, 27 February 1932. Capitalisation in the original.

84. J.A. Laponce, Languages and their Territories (University of Toronto Press, Toronto, 1987), p 170, cited in H. Giliomee, "'n Algemeen Geldende Basis vir Afrikaans?", Tydskrif vir Geesteswetenskappe, 45, 2 (2005), p 277. Giliomee quotes Laponce on the post-apartheid situation at historically Afrikaans universities where English was introduced as a second medium. Ironically, this also applied half a century earlier when Afrikaans became the main language at some universities.

85. Erlank is the well-known Afrikaans poet, Eitemal.

86. UPA: D-6-5-1-6-22, W.J. du P. Erlank - C.H. Celliers, 21 September 1974.

87. Van der Merwe, “'Taal op Tuks'”, pp 155, 163. The Afrikaans language movement and Afrikaner nationalism were "unstoppable progressive forces" in Afrikaner nationalist writing in the 1960s and 1970s, the time when Pelzer wrote Ad Destinatum. See H. Giliomee, "The Beginnings of Afrikaner Nationalism, 1870-1915", South African Historical Journal, 19 (1987)", p 122. 
council did not embrace the idea of a single medium policy for more than a decade, and uses this as evidence that the council was not favourably oriented towards Afrikaans. ${ }^{88}$ He states:

... it should thus be apparent that the University Council which was in the first place responsible for determining the policy of the institution, was for many years not in favour of an Afrikaans orientation. 89

However, a close study of the initial discussions on the language medium issue shows that the college authorities realised they could not continue with an Englishonly policy. The action of the council shows (contrary to what Pelzer claims, as cited above) that the council was from the beginning willing to accommodate a language other than English, in contrast to many other university colleges, where no steps were taken to introduce another medium. Furthermore, because certain colleges pursued a default English-only policy, it was difficult to sustain a bilingual college, because English students would probably favour exclusively English institutions. It can be concluded that one problem with regard to the medium question was that if bilingual education was the ideal of government, it should have been pursued at other colleges. ${ }^{90}$ The failure of the bilingual policy also points to some unwillingness among white South Africans, and English speakers more particularly, to embrace bilingualism. Indeed, this debate at the TUC exposed the weaknesses of broad South African notions, particularly those on the practical implementation of the ideal and the implications of accommodating diverse linguistic and cultural needs.

\section{Conclusion}

The response of the TUC to the presence of two languages on its campus highlights a number of interesting issues related to a bilingual educational environment. It is significant that the student voice became a main factor in adjusting the language policy of the institution. While initially the college was only prepared to accommodate both white languages symbolically, it was student action in the form of petitions to the TUC's senate and council which led to the official introduction of a second medium. ${ }^{91}$ The matter of language at the college was far more nuanced and complex than it is presented in the institution's official history. The way the language question was addressed demonstrates neither an aggressively anti-Afrikaans attitude, nor a coordinated drive to promote the Afrikaans language. Rather, what is evident is a willingness on the part of college authorities to accommodate diverse interests and efforts to cope with the practical difficulties attached to such an aspiration. This is

88. Van der Merwe, "Taal op Tuks", p 153.

89. Rautenbach (ed.), Ad Destinatum, p 49. My own translation.

90. B.L. Strydom, “'To buttress the ideal of national unity': Broad South Africanism and Higher Education in the Early Twentieth Century", South African Historical Journal, 68, 2 (June 2016), pp 163-179.

91. The University of Pretoria's official announcement, made in 2015, of the return to a single medium policy was also driven by student demands. Interview with Prof N.J. Grové, Pretoria, 19 May 2017. 
particularly apparent in the time dedicated to discussions on the matter and the somewhat ineffectual attempts to accommodate both teaching mediums. What was also evident, in parallel to these attempts, was a growing demand for more exclusive language rights for Afrikaners.

It is also clear that in the course of time, language became increasingly important to Afrikaner nationalists as a symbol of identity; language rights became synonymous with Afrikaner rights. So much so, that the point of dispute in matters of white identity politics at the time became one's language. While in essence the idea of conciliation and broad South Africanism did not oppose the place of Afrikaans, it can be argued that the move towards Afrikaans-medium classes arose from a conciliatory spirit on the part of the college's administration. But in practice, the strengthening of separate language rights set up barriers between the two groups. The college was left in an impossible position because the authorities felt that English students would be inclined to leave the TUC if the Afrikaans medium became too dominant. Furthermore it appears that some Afrikaans students began to favour institutions which catered more specifically for them..$^{92}$ Therefore, the language question became an obstacle to bringing students together and showed that white South Africans of both language groups had not really bought into the project of conciliation, which in this context became synonymous with bilingualism. It can also be argued that it was perhaps too much to expect from a young institution such as TUC which, in its formative years, still lacked the atmosphere of tradition and university culture necessary to promote a lasting new white identity on its campus.

\section{REFERENCES}

Basson, M.A., “Die Britse Invloed in die Transvaalse Onderwys, 1836-1907”, Archives Yearbook for South African History, 19, II (Government Printer, Pretoria, 1956).

Boucher, M., "The University of the Cape of Good Hope and the University of South Africa, 1873-1946: A Study in National and Imperial Perspective", Archives Yearbook for South African History, 35, I (Government Printer, Pretoria, 1974).

Brand, B., "Imagining a Multilingual Academy: Rethinking Language in Higher Education", South African Journal of Higher Education, 17, 3 (2003).

Dubow, S., "Colonial Nationalism, the Milner Kindergarten and the rise of 'South Africanism', 1902-1910", History Workshop, 43 (1997).

Dubow, S., "Imagining the New South Africa in the Era of Reconstruction", in Omissi, D. and Thompson, A. (eds), The Impact of the South African War (Palgrave, New York, 2002).

Foley, A., "Language Policy for Higher Education in South Africa: Implications and Complications", South African Journal of Higher Education, 18, 1 (2004).

Foster, J., Washed in Sun: Landscape and the Making of White South Africa (University of Pittsburgh Press, Pittsburgh, 2008).

92. The percentage of Afrikaans-speaking students who supported the idea of a single Afrikaans medium institution is unknown. See Van der Merwe, "Taal op Tuks", p 158. 
Giliomee, H., “'n Algemeen Geldende Basis vir Afrikaans?", Tydskrif vir Geesteswetenskappe, 45, 2 (2005).

Giliomee, H., The Afrikaners: Biography of a People (Tafelberg, Cape Town, 2009).

Giliomee, H., "The Beginnings of Afrikaner Nationalism, 1870-1915", South African Historical Journal, 19 (1987).

Hibbert, L. and Van der Walt, C., Multilingual Universities in South Africa: Reflecting Society in Higher Education (Multilingual Matters, Bristol, Buffalo and Toronto, 2014).

Hofmeyr, I., "Building a Nation from Words: Afrikaans Language, Literature and Ethnic Identity, 1902-1924", in Marks, S. and Trapido, S. (eds), The Politics of Race, Class and Nationalism in Twentieth-Century South Africa (Longman, New York, 1987).

Laponce, J.A., Languages and their Territories (University of Toronto Press, Toronto, 1987).

Marks, S. and Trapido, S., "The Politics of Race, Class and Nationalism", in Marks, S. and Trapido, S. (eds), The Politics of Race, Class and Nationalism in TwentiethCentury South Africa (Longman, New York, 1987).

Rautenbach, C.H. et al (ed.), Ad Destinatum: Gedenkboek van die Universiteit van Pretoria (Voortrekkerpers, Johannesburg, 1960).

Steyn, J.C., "Die Taalstryd aan die Grey Universiteitskollege ten Tye van die Rektoraat van D.F. Malherbe", Acta Academica, 25, 4 (December 1993).

Steyn, J.C., “'n Rektor Skors sy Voorganger oor 'n Onstuimige Hoofstuk uit die Taalstryd aan die UKOVS", Joernaal ver Eietydse Geskiedenis, 20, 1 (June 1995).

Strydom, B., "War, Education and Identity: Discord at the Transvaal University College (1914-1919)", Historia, 59, 2 (November 2014).

Strydom, B.L., “To buttress the ideal of national unity': Broad South Africanism and Higher Education in the Early Twentieth Century", South African Historical Journal, 68, 2 (June 2016).

Thompson, A., "The Languages of Loyalism in Southern Africa, c. 1870-1939", Oxford Historical Review, CVVIII, 477 (June 2003).

Van der Merwe, D.M., '“Taal op Tuks' A Reappraisal of the Change in Language Policy at the University of Pretoria, 1932", Historia, 53, 2 (November 2008). 